\title{
PENGARUH PERTAMBAHAN KASUS COVID-19 ANTARA PROVINSI DKI JAKARTA DAN JAWA TIMUR MENGGUNAKAN VECTOR AUTOREGRESSIVE
}

\author{
(The Effect Of Additional Case Of Covid-19 Between DKI Jakarta And East Java Province \\ Using Vector Autoregressive)
}

\author{
Adina Astasia ${ }^{1}$, Surya Wagito' ${ }^{2}$ Fitri Bunga Adelia ${ }^{3}$, You Ari Faeni ${ }^{4}$ \\ 1,2,3,4Badan Pusat Statistik Kabupaten Ogan Komering Ulu Timur \\ Jalan Adiwiyata KM.07, Sp.Lengot, Kotabaru Selatan, Martapura \\ E-mail: adinaastasia@bps.go.id
}

\begin{abstract}
ABSTRAK
Pertambahan kasus covid-19 di Jakarta dan Jawa Timur menjunjukkan tren yang saling berkesinambungan. Mobilitas penduduk yang tinggi merupakan salah satu faktor yang mempengaruhi penyebaran penyakit di berbagai wilayah. Charu (2017) melakukan studi mengenai penyebaran penyakit influenza di Amerika Serikat selama 2002-2010 dengan hasil bahwa setiap epidemi dapat dikaitkan dengan peristiwa penularan jarak jauh yang akan memicu transmisi selanjutnya. Penelitian ini bertujuan untuk mengetahui efek dinamika pertambahan kasus covid-19 di Jakarta dan Jawa Timur. Variabel yang digunakan pada penelitian ini adalah data pertambahan kasus covid-19 di Jakarta dan Jawa Timur dari @kawalcovid19. Metode Vector Autoregressive (VAR) dengan Impulse Response Function (IRF) dan Variance Decomposition (VDC) dipilih karena mampu menjelaskan respon yang terjadi di suatu wilayah terhadap shock di wilayah itu sendiri dan wilayah lain. Penelitian ini membuktikan adanya pengaruh positif dan signifikan pertambahan kasus covid-19 di Jakarta terhadap pertambahan kasus covid-19 di Jawa Timur.
\end{abstract}

Kata kunci: Covid-19, Jakarta, Jawa Timur, Vector Autoregressive

\section{ABSTRACT}

The increasing of covid-19 cases in Jakarta and East Java shows a continuous trend. High population mobility is one of the factors that influence the spread of disease in various regions. Charu (2017) conducted a study on the spread of influenza in the United States during 2002-2010 with the results that each epidemic can be associated with a remote transmission event that will trigger further transmission. This study aims to determine the dynamic effects of the increase in covid-19 cases in Jakarta and East Java. The variables used in this study were data on the increase in covid-19 cases in Jakarta and East Java from @ kawalcovid-19. The Vector Autoregressive (VAR) method with Impulse Response Function (IRF) and Variance Decomposition (VDC) was chosen because it is able to explain the response that occurs in a region to shock in the region itself and in other regions. This research proves that there is a positive and significant effect of the increase in Covid-19 cases in Jakarta on the increase in Covid-19 cases in East Java.

Keywords: Covid-19, Jakarta, West Java, Vector Autoregressive

\section{PENDAHULUAN}

Pada akhir tahun 2019, dunia dikejutkan dengan menyebarnya covid-19 di Wuhan, China dan mulai menyebar di Indonesia pada bulan Maret 2020. Penyebaran penyakit ini tergolong sangat mudah sebagaimana penyebaran influenza biasa. Kementerian Kesehatan Republik Indonesia menyatakan bahwa covid-19 dapat menular baik melalui kontak langsung, maupun tidak langsung. Penularan secara tidak langsung paling banyak terjadi karena virus ini dapat bertahan di udara dan benda-benda hingga 2-3 hari.

Pada pertengahan Juni 2020, Jawa Timur menjadi sorotan karena peningkatan kasus covid-19 di provinsi tersebut. Angka yang tercatat di @kawalcovid-19 menunjukkan keselarasan pertumbuhan kasus covid-19 antara Jakarta dan Jawa Timur. Sebagai pusat ekonomi, mobilitas 146 
penduduk dalam dan antar kedua provinsi ini sangat tinggi. Gerbang Kertosusila di Jawa Timur merupakan wilayah metropolitan terbesar kedua di Indonesia setelah Jabodetabek yang berpusat di Jakarta. Mobilitas penduduk yang tinggi merupakan salah satu faktor yang mempengaruhi penyebaran penyakit menular (Charaudeau, 2014; Chen, 2008). Studi serupa oleh Cai (2020) menyimpulkan mobilitas manusia berpengaruh dalam penurunan prevalensi pandemi influenza. Charu (2017) melakukan studi mengenai penyebaran penyakit influenza di Amerika Serikat selama 2002-2010. Hasil studi tersebut menunjukkan bahwa setiap epidemi dapat dikaitkan dengan peristiwa penularan jarak jauh sebagai awal, yang kemudian memicu transmisi selanjutnya.

Penelitian ini bertujuan untuk menganalisis efek dinamika petambahan kasus covid-19 di Jakarta terhadap kasus covid-19 di Jawa Timur.

\section{METODE}

Data yang digunakan dalam penelitian ini adalah data harian pertambahan kasus covid-19 dari tanggal 18 Maret 2020 s.d. 17 Agustus 2020 di Jakarta $\left(y_{1}\right)$ dan Jawa Timur $\left(y_{2}\right)$. Data bersumber dari @kawalcovid-19. Pemodelan dilakukan dengan bantuan perangkat lunak R package vars.

Analisis dilakukan dengan metode Vector Autoregressive (VAR) dengan pengembangan analisis menggunakan Impulse Response Function (IRF) dan Variance Decomposition (VDC).

Vector Autoregressive (VAR) merupakan pengembangan dari Autoregression (AR) dengan 1 variabel yang dapat digunakan untuk menggambarkan hubungan timbal balik antar variabel (Tsay, 2005). Model umum VAR(1) adalah:

$$
y_{t}=a_{0}+\emptyset y_{t-1}+e_{t}
$$

dimana:

$\boldsymbol{y}_{\boldsymbol{t}}=$ vektor dari variabel dependen/respon

$\boldsymbol{a}_{0}=$ vektor intersep

$\emptyset=$ square matrik koefisien

$e_{t}=$ vektor residual.

Untuk model dengan dua variabel tanpa intersep, maka model VAR(1) dapat dituliskan:

$y_{1, t}=\emptyset_{11} y_{1, t-1}+\emptyset_{12} y_{2, t-1}+e_{1}$

$y_{2, t}=\emptyset_{21} y_{1, t-1}+\emptyset_{22} y_{2, t-1}+e_{2}$

Uji Kausalitas Granger dapat digunakan untuk menguji hubungan antar variabel, namun tidak untuk estimasi terhadap model. Misalkan terdapat 2 variabel $y_{1}$ dan $y_{2}$ maka kemungkinan hasil yang muncul dari uji kausalitas Granger adalah:

- $\quad y_{1}$ menyebabkan $y_{2}$

- $\quad y_{2}$ menyebabkan $y_{1}$

- $\quad y_{1}$ menyebabkan $y_{2}$ dan $y_{2}$ menyebabkan $y_{1}$

- $y_{1}$ dan $y_{2}$ tidak ada hubungan

Model kausalitas Granger dinyatakan sebagai berikut, $y_{1, t}=\alpha_{1} y_{1, t-1}+\cdots+\alpha_{n} y_{1, t-n}+\beta_{1} y_{2, t-1}+\cdots+\beta_{n} y_{2, t-n}+e_{1}$

$y_{2, t}=\alpha_{1} y_{2, t-1}+\cdots+\alpha_{n} y_{2, t-n}+\beta_{1} y_{1, t-1}+\cdots+\beta_{n} y_{1, t-n}+e_{2}$

dengan hipotesis dari persamaan tersebut sebagai berikut, 
$H_{0}: \beta_{1}=\beta_{2}=\cdots=\beta_{n}=0$

dimana $H_{0}$ berarti tidak terdapat hubungan antara variabel.

Impulse Response Function (IRF) merupakan metode untuk melihat respon suatu variabel terhadap shock dari variabel lain. Respon suatu variabel yang dimaksud bisa saja terjadi pada saat tersebut atau beberapa waktu di masa mendatang bergantung pada lag yang signifikan.

Green (2003) menyatakan bahwa pada suatu persamaan yang mendapat shock dari suatu variabel, maka pada suatu titik akan tercapai keseimbangan dimana respon yang terjadi akan semakin mengecil dan kembali pada titik keseimbangan. Pergerakan dari respon hingga mencapai titik keseimbangan disebut Impulse Response Function VAR.

Variance Decomposition (VDC) merupakan metode yang digunakan untuk melihat seberapa besar pengaruh proporsi shock suatu variabel terhadap variabel itu sendiri dan proporsi shock dari variabel lain. Secara sederhana, jika IRF memperlihatkan seberapa besar pengaruh suatu shock terhadap variabel, maka variance decomposition memberikan informasi mengenai pengaruh setiap shock yang terjadi pada suatu variabel dan memperlihatkan hubungan timbalbalik antar variabel.

\section{HASIL DAN PEMBAHASAN}

Langkah awal dalam pemodelan data deret waktu adalah identifikasi model. Identifikasi model VAR dilakukan melalui plot $A C F$ dan PACF variabel yang dapat dilihat pada Gambar 1.

\section{Series 1}

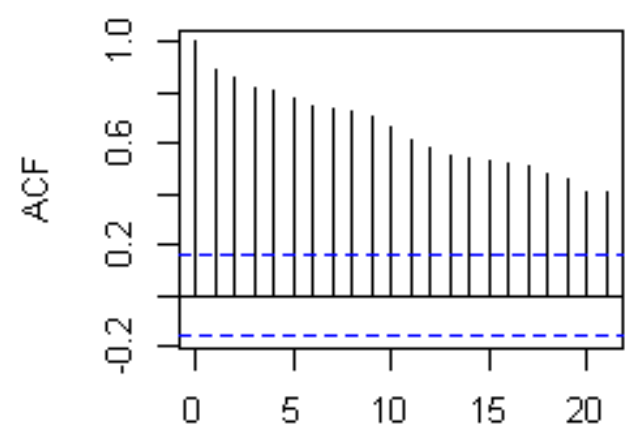

Lag

\section{Series 1}

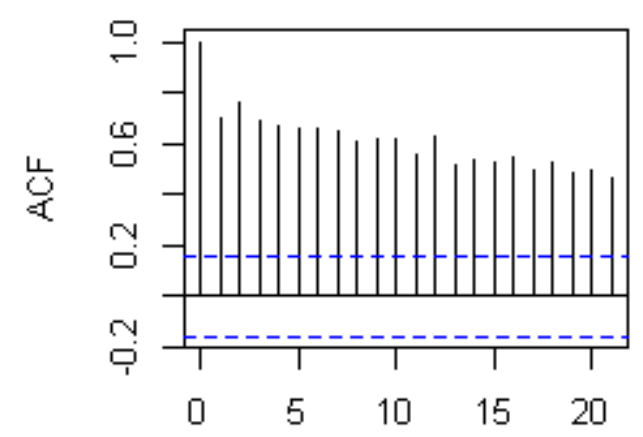

Lag

\section{Series y1}

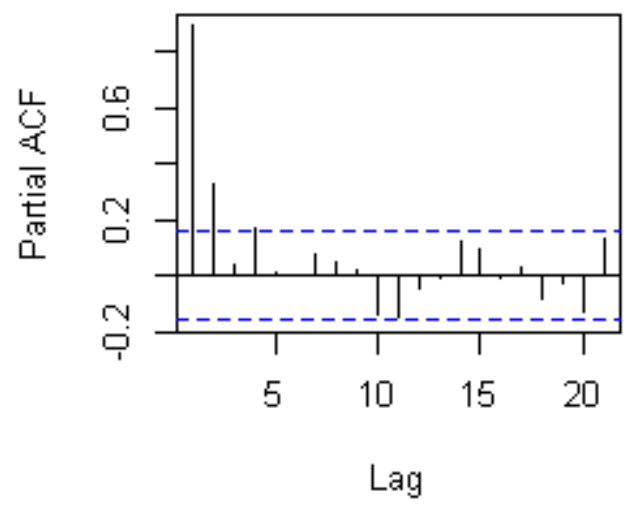

Series $y 2$

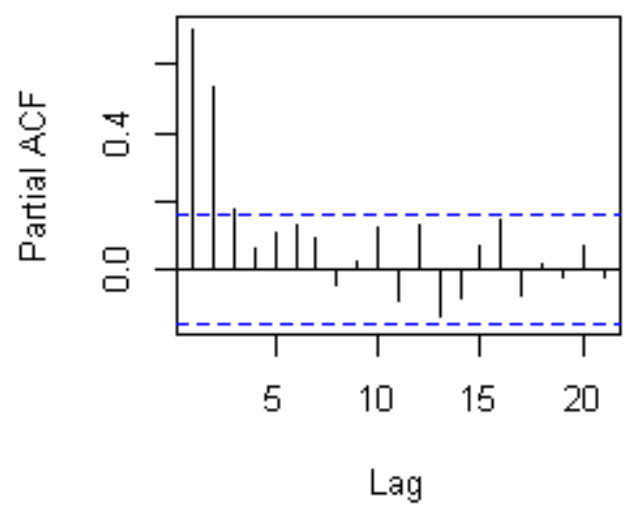

Gambar 20. Plot ACF dan PACFVariabel Penelitian 
Plot $A C F$ pada kedua variabel menunjukkan pola dying down sementara plot PACF cut off . Oleh karena itu model yang sesuai adalah model $V A R(\mathrm{p})$. Oleh karena plot PACF terpotong pada lag 1 dan 2 maka kemungkinan model yang dapat digunakan adalah VAR (1) maupun VAR (2). Nilai $A I C$ pada model $V A R(2)$ adalah sebesar 3415.69 sementara $V A R(1)$ sebesar 3508.68 . Dilihat dari nilai $A I C$ maka sebenarnya model $V A R$ (2) lebih baik dibandingkan VAR (1), namun untuk kesederhanaan model dipilih model $V A R(1)$ dalam penelitian ini.

Estimasi Model VAR (1) berarti bahwa suatu variabel tidak hanya dipengaruhi nilai masa lalu variabel tersebut tetapi juga dipengaruhi nilai masa lalu variabel lainnya. Pemodelan dilakukan dengan metode Ordinary Least Square (OLS) dengan hasil sebagai berikut:

Tabel 11. Pemodelan VAR Pertambahan Kasus covid-19 di Jakarta dan Jawa Timur

\begin{tabular}{lrrrr}
\hline \multicolumn{1}{c}{ Variabel } & Koefisien & $\begin{array}{c}\text { Standar } \\
\text { Eror }\end{array}$ & t-value & p-value \\
\hline Persamaan $\boldsymbol{y}_{\mathbf{1}}$ & & & & \\
\hline$y_{1, t-1}$ & 0,88971 & 0,04176 & 21,30 & $<2 \times 10^{-16^{*}}$ \\
\hline$y_{2, t-1}$ & 0,10937 & 0,04273 & 2,56 & $0,0115^{*}$ \\
\hline Persamaan $\boldsymbol{y}_{\mathbf{2}}$ & & & & \\
\hline$y_{1, t-1}$ & 0,40936 & 0,06719 & 6,092 & $9,07 \times 10^{-9 *}$ \\
\hline$y_{2, \boldsymbol{t}-\mathbf{1}}$ & 0,52699 & 0,06874 & 7,666 & $2,11 \times 10^{-12^{*}}$ \\
\hline${ }^{*}$ signifikan pada taraf nyata $5 \%$ & & &
\end{tabular}

Berdasarkan model pada Tabel 1. dapat dilihat bahwa seluruh nilai koefisien $V A R$ bernilai $<|1|$ sehingga dapat disimpulkan bahwa sistem VAR telah stasioner (Wei, 2006). Model VAR (1) yang diperoleh dapat dituliskan sebagai berikut:

$$
\begin{aligned}
& \hat{y}_{1, t}=0,88971 y_{1, t-1}+0,10937 y_{2, t-} \\
& \hat{y}_{2, t}=0,40936 y_{1, t-1}+0,52699 y_{2, t-}
\end{aligned}
$$

Model pada Persamaan (1) mengenai pertambahan kasus covid-19 di Jakarta merupakan model yang fit. Terdapat hubungan signifikan positif antara pertambahan kasus covid-19 di Jawa Timur periode yang lalu $\left(y_{2, t-1}\right)$ terhadap pertambahan kasus covid-19 di Jakarta periode sekarang $\left(y_{1, t}\right)$, dengan koefisien sebesar 0,10937. Persamaan (2) juga merupakan model yang fit. Terdapat hubungan signifikan positif antara pertambahan kasus covid-19 di Jakarta periode yang lalu $\left(y_{1, t-1}\right)$ terhadap pertambahan kasus covid-19 di Jawa Timur periode sekarang $\left(y_{2, t}\right)$, dengan koefisien sebesar 0,40936.

Analisis dilanjutkan dengan pengujian kausalitas Granger dengan

$\mathrm{H}_{0}: y_{1}$ tidak granger cause $y_{2}$

$\mathrm{H}_{1}: y_{1}$ granger cause $y_{2}$

dengan kriteria uji Tolak $\mathrm{H}_{0}$ jika $p$-value $\leq \alpha(0,05)$. Diperoleh $p$-value sebesar $3,434 \times 10^{-9}$, sehingga $H_{0}$ ditolak dan dapat disimpulkan bahwa $y_{1}$ granger cause $y_{2}$.

Analisis Impulse Response Function (IRF) digunakan untuk mendeteksi respon dari setiap variabel akibat perubahan/shock dari variabel lainnya. IRF dapat dilihat dari Gambar 2. 


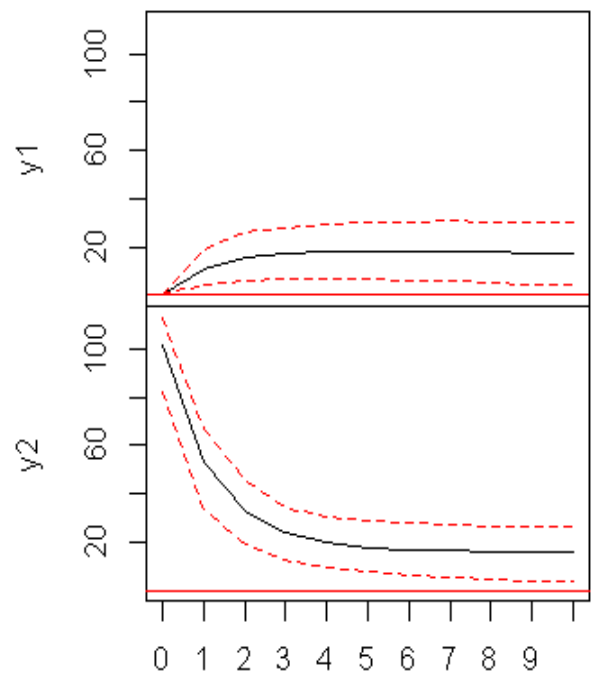

$95 \%$ Bootstrap $\mathrm{Cl}, 100$ runs

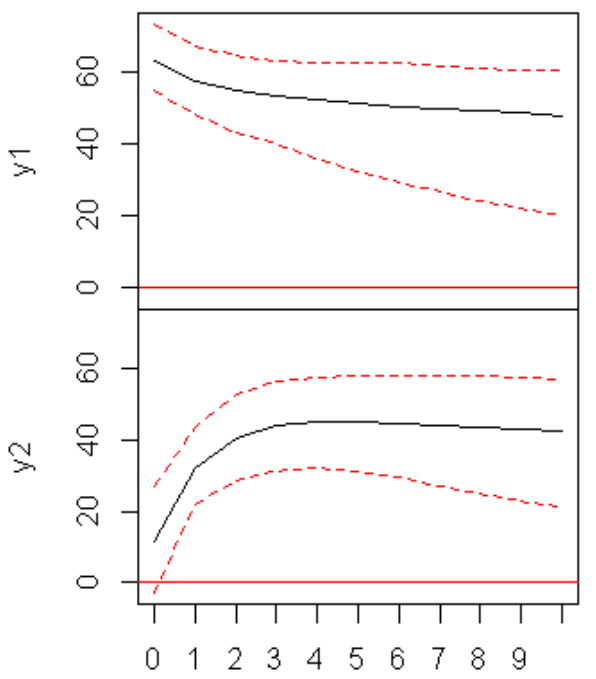

$95 \%$ Bootstrap $\mathrm{Cl}, 100$ runs

Gambar 2. Impulse Response Function (IRF) variabel penelitian

Berdasarkan Gambar 2. dapat dilihat bahwa perubahan atau shock pada pertambahan kasus covid-19 di Jawa Timur $\left(y_{2}\right)$ memberikan pengaruh positif terhadap pertambahan kasus covid-19 di Jakarta $\left(y_{1}\right)$. Begitupun jika terjadi perubahan atau shock pada pertambahan kasus covid-19 di Jakarta $\left(y_{1}\right)$ maka respon $y_{2}$ juga positif. Namun dapat dilihat bahwa respon $y_{2}$ jika terjadi shock pada $y_{1}$ lebih besar dibanding respon $y_{1}$ jika terjadi shock pada $y_{2}$. Hal ini mengindikasikan bahwa pengaruh pertambahan kasus covid-19 di Jakarta terhadap Jawa Timur lebih besar dibandingkan sebaliknya.

Selanjutnya dilakukan Variance Decomposition Analysis (VDC) dengan hasil sebagai berikut:

Tabel 3. Variance Decomposition Analysis (VDC) pada model VAR(1)

\begin{tabular}{lccrccc} 
& \multicolumn{2}{c}{ Persamaan $\boldsymbol{y}_{\mathbf{1}}$} & \multicolumn{3}{c}{ Persamaan $\boldsymbol{y}_{\mathbf{2}}$} \\
Periode & $y_{1}$ & $y_{2}$ & Periode & $y_{1}$ & $y_{2}$ \\
1 & 1,0000000 & 0,00000000 & $\mathbf{1}$ & 0,01253173 & 0,9874683 \\
2 & 0,9835404 & 0,01645959 & $\mathbf{2}$ & 0,08070815 & 0,9192919 \\
3 & 0,9655123 & 0,03448768 & $\mathbf{3}$ & 0,16419069 & 0,8358093 \\
4 & 0,9510868 & 0,04891316 & $\mathbf{4}$ & 0,24167550 & 0,7583245 \\
5 & 0,9402974 & 0,05970256 & $\mathbf{5}$ & 0,30711931 & 0,6928807 \\
6 & 0,9322649 & 0,06773510 & $\mathbf{6}$ & 0,36095690 & 0,6390431 \\
7 & 0,9261879 & 0,07381213 & $\mathbf{7}$ & 0,40523012 & 0,5947699 \\
8 & 0,9214868 & 0,07851324 & $\mathbf{8}$ & 0,44196773 & 0,5580323 \\
9 & 0,9177664 & 0,08223361 & $\mathbf{9}$ & 0,47281342 & 0,5271866 \\
10 & 0,9147597 & 0,08524032 & $\mathbf{1 0}$ & 0,49902263 & 0,5009774
\end{tabular}

Berdasarkan hasil VDC pada Tabel 4. dapat diketahui bahwa pertambahan kasus covid-19 di Jakarta $\left(y_{1}\right)$ dipengaruhi oleh variabel itu sendiri $\left(y_{1}\right)$ hampir sepanjang periode. Sementara pertambahan kasus covid-19 di Jawa Timur $\left(y_{2}\right)$ dipengaruhi oleh variabel itu sendiri $\left(y_{2}\right)$ pada periode awal namun pengaruhnya semakin menurun sepanjang periode didekomposisi dengan tambahan pengaruh dari variabel $y_{1}$ sampai sebesar $49,90 \%$ pada periode ke- 10 . Hasil ini sejalan 
dengan hasil IRF yang menyatakan bahwa pengaruh pertambahan kasus covid-19 di Jawa Timur lebih dipengaruhi pertambahan kasus covid-19 di Jakarta, namun hal sebaliknya tidak terjadi.

\section{KESIMPULAN}

Kesimpulan penelitian ini adalah terdapat pengaruh positif dan signifikan pertambahan kasus covid-19 Jakarta terhadap pertambahan kasus covid-19 Jawa Timur, begitupun sebaliknya. Teradapat pengaruh positif dan signifikan pertambahan kasus covid-19 Jawa Timur terhadap Jakarta.

Namun demikian, melalui analisis Impulse Response Function (IRF) serta Variance Decomposition Analysis (VDC) terlihat bahwa pertambahan kasus covid-19 di Jawa Timur sangat dipengaruhi pertambahan kasus covid-19 di Jakarta. Respon pertambahan kasus covid-19 di kedua Provinsi pun banyak dipengaruhi oleh pertambahan kasus positif covid-19 dari Jakarta. Sedangkan pengaruh dari Jawa Timur hanya mempengaruhi dirinya sendiri yang semakin jauh periodenya maka akan semakin dipengaruhi pertambahan kasus dari Jakarta.

\section{DAFTAR PUSTAKA}

Cai, Y., Li, J., Kang, Y., Wang, K., \& Wang, W. (2020). The fluctuation impact of human mobility on the influenza transmission. Journal of the Franklin Institute.

Charaudeau S, Pakdaman K, Boelle P-Y. (2014). Commuter Mobility and the Spread of Infectious Diseases: Application to Influenza in France. PLoS ONE 9(1): e83002.

Charu V, Zeger S, Gog J, Bjørnstad ON, Kissler S, Simonsen L, et al. (2017) Human mobility and the spatial transmission of influenza in the United States. PLoS Comput Biol 13(2): e1005382.

Chen, Lin \& Wilson, Mary. (2008). The Role of the Traveler in Emerging Infections and Magnitude of Travel. The Medical clinics of North America (92) 1409-32.

Tsay, R. S. (2005). Analysis of financial time series. Hoboken, NJ: Wiley-Interscience. ISBN: 978-0-47169074-0

Wei, W.W.S. (2006). Time Series Analysis: Univariate and Multivariate Methods Second Edition. Pearson: United States. 